\title{
Effect of mass media and Internet on sexual behavior of undergraduates in Osogbo metropolis, Southwestern Nigeria
}

This article was published in the following Dove Press journal:

Adolescent Health, Medicine and Therapeutics

28 January 2014

Number of times this article has been viewed

\author{
Olusesan S Asekun- \\ Olarinmoye \\ Esther O Asekun- \\ Olarinmoye ${ }^{2}$ \\ Wasiu O Adebimpe 2 \\ Akin G Omisore ${ }^{2}$ \\ 'Department of Mass Communication, \\ Babcock Business School, Babcock \\ University, Ilisan-Remo, Ogun State, \\ Nigeria; ${ }^{2}$ Department of Community \\ Medicine, Faculty of Clinical Sciences, \\ College of Health Sciences, \\ Osun State University, Osogbo, \\ Osun State, Nigeria
}

Introduction: The influence of media portrayals of sexual attitudes and normative expectations of young people at a critical developmental stage is of public health concern.

Objectives: To examine the role of mass media and Internet utilization in shaping the sexual health attitudes and behaviors of young undergraduates in Osogbo metropolis, Osun State, Nigeria.

Materials and methods: In a descriptive cross-sectional study, 400 undergraduates were selected using a multistage random sampling technique. Four hundred and fifty pretested, semistructured questionnaires were distributed; of these, 400 were returned properly filled. Data were analyzed using SPSS statistical software version 16.

Results: Mean age of respondents \pm standard deviation was $23.6 \pm 2.99$ years. Most were aware of the various forms of mass media (>95\%). Most (64.0\%) respondents spent 1-5 hours watching television, daily, and most used the Internet often. About $38.3 \%$ and $24.2 \%$ of respondents used the Internet and radio/television, respectively, as sources of information on sexual issues. Most respondents used the Internet for school assignments $(83.0 \%, \mathrm{n}=332)$, electronic mail $(89.0 \%$, $\mathrm{n}=356)$, and for accessing sexually explicit materials (74.5\%, $\mathrm{n}=298)$. Most of the respondents (73.5\%) opined that the Internet has a bad influence on youths' sexual behavior, although accessing the Internet for sexual material or movies was acceptable to $25.3 \%$ of them. Of the 226 respondents who had ever had sex, $226(100 \%), 37$ (16.4\%), 31 (13.7\%), and $10(4.4 \%)$ practiced coitus, oral sex, masturbation, and anal sex, respectively; 122 (54.0\%) always used condoms, whereas 90 (40.0\%) never used condoms during sexual activity; 33 (14.6\%) had had sex with commercial sex workers. Further analysis showed that those who were yet to marry (single) were less likely to be sexually experienced than those who were married (adjusted odds ratio $[\mathrm{AOR}]=0.075$, $95 \%$ confidence interval $[\mathrm{CI}]=0.008-0.679$ ), and those who said accessing the Internet for sexual material is not acceptable to them were also less likely to be sexually experienced than those to whom it was acceptable ( $\mathrm{AOR}=0.043,95 \% \mathrm{CI}=0.016-0.122$ ). Predictors of having multiple sexual partners include the sex of the respondent and the frequency of Internet use, with females ( $\mathrm{AOR}=0.308,95 \% \mathrm{CI}=0.113-0.843$ ) and those who rarely use the Internet less likely to have multiple sexual partners.

Conclusion: We conclude that uncontrolled exposure to mass media and Internet could negatively influence the sexual patterns and behavior of youths.

Keywords: mass media, Internet, sexual behavior, undergraduates

\section{Introduction}

Mass media is defined as those media that are designed to be consumed by large audiences through the agencies of technology. ${ }^{1,2}$ An array of communication media reaches large numbers of the public, including radio, television, movies, newspapers, 
and magazines. The Internet is a worldwide, publicly accessible network of interconnected computer networks that transmits information and services such as electronic mail, online chat, title transfer, interlinked web pages, and other documents of the World Wide Web. ${ }^{3}$

Media influences on sexual behavior were first reported in a sex education newsletter in $1981,{ }^{4}$ and since then several overviews have examined adolescents' use of media as a source of information and its possible effect on their sexual behavior. ${ }^{5-8}$ Adolescents are vigorous users of the information broadcast in the media, ${ }^{9}$ and concern has been raised about the influence of media portrayals on sexual attitudes and the normative expectations of these adolescents at a critical developmental stage. ${ }^{10}$ The mass media and the Internet have their advantages in terms of providing necessary information for young people on sexual health and healthy sexual relationships, ${ }^{3}$ but many studies have shown that mass media negatively influences teens in their sexual behaviors. ${ }^{1,9,11,12}$ Over the past two decades, studies have shown an overall increase in the number of portrayals of and the amount of discussion about sex in these media and an increase in the explicitness of these portrayals. ${ }^{13-16}$ Furthermore, television research shows a fairly consistent sexual message across television genres: most portrayals of sex depict or imply sexual intercourse between unmarried adults, with little or no reference to sexually transmitted infections or acquired immunodeficiency syndrome (AIDS), pregnancy, or use of contraception. ${ }^{17}$

Sexual discussions and displays are increasingly frequent and explicit in all forms of the mass media. ${ }^{3}$ The Internet, the use of which is growing more rapidly than any previous technology, ${ }^{18}$ has dramatically increased the availability of sexually explicit content. ${ }^{3}$ One content analysis found that the inclusion of sexual content that ranged from flirting to sexual intercourse had increased from slightly more than half of television programs in 1997-1998, to more than two thirds of the programs in the 1999-2000 season. Depictions of intercourse (suggestive or explicit) occurred in one of every ten programs..$^{19}$ A US study examining 1,276 youth-directed programs broadcast in $2001-2002$ showed that $82 \%$ of episodes featured sexual talk and $67 \%$ featured sexual behavior, with $11 \%$ implying, and $4 \%$ portraying sexual intercourse. ${ }^{20}$

Little is known, however, of the relationship between the media and young people's sexual behavior in Nigeria, or indeed in developing countries in general, because of the dearth of studies in this area. The alarming increase of rape, teenage pregnancies, septic abortions, and sexually transmitted infections, especially human immunodeficiency virus (HIV), among undergraduates in Nigeria ${ }^{21}$ makes research into the effects of the mass media and the Internet on their sexual behavior even more important.

\section{Materials and methods}

This descriptive, cross-sectional study was carried out in Osogbo, the capital of Osun State, Nigeria; the target population was undergraduates in Osogbo metropolis. The town has three universities: Ladoke Akintola University of Technology Teaching Hospital (LAUTECH); Fountain University; and Osun State University. Questionnaires were administered to students at two randomly selected schools within the Universities; the lower-level medical students of Osun State University, and the upper-level basic medical laboratory science students at LAUTECH. Ethical approval to conduct this study was obtained from the Research Ethics Committee of LAUTECH, and further permission was sought and obtained from the Provost, College of Health Sciences, Osun State University, authorizing us to conduct the survey there also. In addition, verbal informed consent was obtained from each respondent.

A multistage sampling technique was used to select the respondents. An initial sample size of 340 was arrived at using the Leslie Fischer's formula for populations smaller than $10,000 .{ }^{22}$ However, to increase representativeness and to remedy for nonresponse, a total of 450 pretested semistructured questionnaires were distributed. This self-administered questionnaire was divided into four sections. The first section comprised sociodemographic characteristics of respondents; the second section dealt with awareness of and use of various forms of mass media; the third section examined patterns of sexual behavior of respondents; and the last section dealt with respondents' attitudes about, and use of the Internet and its effects, especially on sexual behaviors.

The questionnaires were manually sorted and analyzed using SPSS statistical software, version 16 (IBM Corporation, Armonk, NY, USA). The validity of the data collected was ensured by double entry and by random checks for errors. Relevant frequency distribution tables and summary measures were generated. The chi-square test was used to demonstrate relationships between categorical variables, and the level of significance was set at $P<0.05$, and a $95 \%$ confidence interval $(95 \% \mathrm{CI})$, for all inferential analyses. Logistic regression analysis was used to identify predictors of being sexually experienced (that is, those who have ever had sex) and of having multiple sexual partners. In the logistic regression tables, number of television viewing hours was regrouped into two groups of "less than" or "equal to and more than" the mean viewing hours. 
Outcome variables for the attitudes of respondents were scored using a five-point Likert scale (strongly agree, agree, undecided, disagree, strongly disagree). These ratings were compressed to agree, undecided, and disagree in the logistic regression tables.

\section{Results}

Of the 450 questionnaires distributed, 400 completed questionnaires were returned, resulting in a response rate of $88.9 \%$. Table 1 shows the sociodemographic characteristics of the 400 respondents. Most were between 20-24 years of age $(59.5 \%)$ and $25-29$ years of age $(32.8 \%)$, with a mean age \pm standard deviation of $23.6 \pm 2.99$ years; the respondents were mainly female $(n=227,56.8 \%)$, Christian $(n=303$, $75.8 \%)$, and single $(n=372,93.0 \%)$.

Most of the respondents were aware of the various forms of mass media, such as radio and television (99.5\%), films (95.0\%), newspapers and magazines (96.5\%), home videos (videos viewed at home) (91.0\%), and the Internet (98.7\%)

Table I Sociodemographic characteristics of respondents $(n=400)$

\begin{tabular}{|c|c|c|}
\hline Variables & $\mathbf{n}$ & (\%) \\
\hline \multicolumn{3}{|l|}{ Age groups (years) } \\
\hline Less than 20 & 17 & 4.2 \\
\hline $20-24$ & 238 & 59.5 \\
\hline $25-29$ & $13 \mid$ & 32.8 \\
\hline 30 and above & 14 & 3.5 \\
\hline \multicolumn{3}{|l|}{ Sex } \\
\hline Female & 227 & 56.8 \\
\hline Male & 173 & 43.2 \\
\hline \multicolumn{3}{|l|}{ Religion } \\
\hline Christianity & 303 & 75.8 \\
\hline Islam & 92 & 23.0 \\
\hline Traditional & 4 & 1.0 \\
\hline Others & 1 & 0.2 \\
\hline \multicolumn{3}{|l|}{ Marital status } \\
\hline Ever married & 28 & 7.0 \\
\hline Yet to marry (single) & 372 & 93.0 \\
\hline \multicolumn{3}{|l|}{ Ethnicity } \\
\hline Yoruba & 324 & 81.0 \\
\hline Igbo & 69 & 17.2 \\
\hline Hausa & 7 & 1.8 \\
\hline \multicolumn{3}{|l|}{ Level in school } \\
\hline Lower level $^{\dagger}$ & 156 & 39.0 \\
\hline Upper leveltt & 244 & 61.0 \\
\hline \multicolumn{3}{|c|}{ Secondary school attended } \\
\hline Private & 220 & 55.0 \\
\hline Public & 180 & 45.0 \\
\hline \multicolumn{3}{|l|}{ Place of residence } \\
\hline Rural & 46 & 11.5 \\
\hline Urban & 354 & 88.5 \\
\hline
\end{tabular}

Notes: ${ }^{\dagger}$ Lower level includes first-year to third-year students; ${ }^{\dagger}$ upper level includes fourth-year and fifth-year students.

Abbreviation: $\mathrm{n}$, number.
(Table 2). Radio and television were the most accessible to respondents $(n=88,22.0 \%)$, followed by the Internet $(n=60$, $15.0 \%$ ). Many of the respondents were of the opinion that the Internet and radio/television were sources of information on sexual issues ( $n=153,38.3 \%$ and $n=97,24.2 \%$, respectively), whereas more respondents $(n=165,41.3 \%)$ felt that the Internet had effects on sexual behavior, compared with other forms of mass media. Films were the favorite types of television programming for more than half of the respondents (56.3\%), and about a third of respondents $(n=134,33.5 \%)$ spent an average of 3-5 hours daily watching the television (Table 3). Most of the respondents $(n=263,65.8 \%)$ had heard about the Internet from friends. Almost half of the respondents $(n=198,49.5 \%)$ used the Internet often, for such purposes as school assignments $(n=332,83.0 \%)$, email $(n=356,89.0 \%)$, and accessing sexually explicit materials $(n=298,74.5 \%)$. Of the 298 who accessed sexually explicit materials on the Internet, 56 (18.8\%) did so often, 53 (17.8\%) occasionally, and 189 (63.4\%) rarely.

Regarding attitudes toward mass media and the Internet, most respondents disagreed or strongly disagreed that premarital sex $(57.3 \%)$ and accessing the Internet for sexual materials (61.8\%) were acceptable behaviors, and most agreed or strongly agreed that the Internet has a bad influence on youths' sexual behavior (73.5\%) (Table 4). After scoring of outcome variables, $58.9 \%$ of respondents had negative attitudes and $41.1 \%$ had positive attitudes towards the mass media/the Internet and their sexual behavior.

Table 5 shows the sexual behavior patterns of respondents. Most of the respondents were aware of various forms of sexual behaviors, such as masturbation (89.2\%), oral sex (88.0\%), anal sex (84.7\%), and coitus (100\%); and 226 of them $(56.5 \%)$ had experienced sexual intercourse. Of the 226 sexually experienced respondents, 226 (100.0\%), 37 (16.4\%), 31 (13.7\%), and $10(4.4 \%)$ practiced coitus, oral sex, masturbation, and anal sex, respectively; 122 (54.0\%) always used condoms during sexual activity, whereas 90 $(40.0 \%)$ never used condoms; 33 (14.6\%) had had sex with commercial sex workers. About half of the respondents $(\mathrm{n}=117,51.8 \%)$ first had sexual intercourse between 15-19 years of age, and most $(n=171,75.7 \%)$ had $1-2$ sexual partners currently.

Most of the respondents ( $n=371,92.8 \%)$ felt that mass media/the Internet had an effect on their sexual behavior, with 198 (49.5\%) of them agreeing it had both positive and negative effects. Bivariate analysis of the outcome variables showed significant association between being sexually active and the respondents' age $(P=0.001)$, sex $(P=0.004)$, marital status $(P=0.01)$, time spent daily watching 
Table 2 Perceptions of respondents about mass media/the Internet $(n=400)$

\begin{tabular}{|c|c|c|c|c|c|}
\hline Variables & $\begin{array}{l}\text { Radio and } \\
\text { television } \\
\mathbf{n}(\%)\end{array}$ & $\begin{array}{l}\text { Films } \\
\text { n (\%) }\end{array}$ & $\begin{array}{l}\text { Newspapers } \\
\text { and magazines } \\
\text { n (\%) }\end{array}$ & $\begin{array}{l}\text { Home video } \\
\text { n (\%) }\end{array}$ & $\begin{array}{l}\text { Internet } \\
\text { n (\%) }\end{array}$ \\
\hline Awareness & $398(99.5)$ & $380(95.0)$ & $386(96.5)$ & $364(91.0)$ & $395(98.7)$ \\
\hline Readily accessible & $388(97.5)$ & $218(54.5)$ & $90(22.5)$ & $400(100.0)$ & $260(65.0)$ \\
\hline Personal favorite & $99(24.8)$ & $94(23.5)$ & $22(5.5)$ & $56(14.0)$ & $120(30.0)$ \\
\hline Source of information on sexual issues & $97(24.2)$ & $46(I I . I)$ & $37(9.2)$ & $67(16.8)$ & $153(38.3)$ \\
\hline Has effects on sexual behavior & $72(18.0)$ & $57(\mid 4.3)$ & $17(4.2)$ & $89(22.2)$ & $165(4 \mid .3)$ \\
\hline
\end{tabular}

Abbreviation: $\mathrm{n}$, number.

television $(P=0.03)$, frequency of Internet use ( $P=0.0003)$, and frequency of accessing sexually explicit materials on the Internet $(P=0.001)$ (Table 6).

In the analysis of possible predictors of being sexually experienced (Table 7), for the variable "accessing Internet for sexual material/movies is acceptable to me" and using "agree" as the reference, respondents who stated that accessing Internet for sexual material/movies was not acceptable to them were 23 times (1/0.043) less likely to be sexually active (experienced) than those who stated that accessing

Table 3 Use of mass media/the Internet by respondents $(n=400)$

\begin{tabular}{|c|c|}
\hline Variables & n (\%) \\
\hline \multicolumn{2}{|l|}{ Favorite programs on television } \\
\hline Films & $225(56.3)$ \\
\hline News and documentaries & $98(24.5)$ \\
\hline Sports & $22(5.5)$ \\
\hline Education & $55(13.7)$ \\
\hline \multicolumn{2}{|c|}{ Average amount of time spent watching television daily (hours) } \\
\hline $0-2$ & $122(30.5)$ \\
\hline $3-5$ & $134(33.5)$ \\
\hline More than 5 & $85(21.2)$ \\
\hline No response & $59(14.8)$ \\
\hline \multicolumn{2}{|c|}{ Source of knowledge about the Internet } \\
\hline Friends & $263(65.8)$ \\
\hline Parents & $13(3.3)$ \\
\hline School & $93(23.2)$ \\
\hline Others & $31(7.7)$ \\
\hline \multicolumn{2}{|c|}{ Reasons for Internet use (multiple responses allowed) } \\
\hline School assignments & $332(83.0)$ \\
\hline Email & $356(89.0)$ \\
\hline Sports & I $64(4 \mid .0)$ \\
\hline Sex movies and pornography & $298(74.5)$ \\
\hline News & $196(49.0)$ \\
\hline \multicolumn{2}{|l|}{ Frequency of Internet use* } \\
\hline Often & $198(49.5)$ \\
\hline Occasionally & $116(29.0)$ \\
\hline Rarely & $86(21.5)$ \\
\hline \multicolumn{2}{|c|}{ Frequency of accessing sexually explicit materials $(n=298)^{*}$} \\
\hline Often & $56(18.8)$ \\
\hline Occasionally & $53(17.8)$ \\
\hline Rarely & $189(63.4)$ \\
\hline
\end{tabular}

Note: *Often indicates daily to weekly use; occasionally indicates once or twice a month; and rarely indicates once in two to three months.

Abbreviation: $\mathrm{n}$, number. the Internet for sexual material/movies was acceptable; this finding was statistically significant for "disagree" (odds ratio [OR] $=0.043,95 \% \mathrm{CI}=0.016-0.122, P<0.001$ ).

Similarly, for the variable "marital status" and using "ever married" as the reference, those who were single (yet to marry) were about 13 times (1/0.075) less likely to be sexually active than those who were married, and this finding was also statistically significant ( $\mathrm{OR}=0.075,95 \% \mathrm{CI}=0.008-0.679$, $P=0.021$ ). Thus, predictors of level of sexual activity were the attitude "accessing the Internet for sexual material/movies is acceptable to me" and respondents' marital status.

In the analysis of possible predictors for having multiple sexual partners (Table 8), for the variable "sex" and using "male" as the reference, females were about three times $(1 / 0.308)$ less likely to have multiple sexual partners than males, and this was statistically significant $(\mathrm{OR}=0.308,95 \%$ $\mathrm{CI}=0.113-0.843, P=0.022)$.

For the variable "frequency of Internet use" and using "rarely" as the reference, those who used the Internet often were about five and a half times (1/5.450) more likely to have multiple sexual partners than those who rarely used the Internet, and this finding was statistically significant (OR $=5.450,95 \% \mathrm{CI}=1.035-28.703, P=0.045)$. Similarly, for the same variable and using "rarely" as the reference, those who used Internet occasionally were about seven times (1/7.295) more likely to have multiple sexual partners than those who rarely used the Internet, and this finding also was statistically significant $(\mathrm{OR}=7.295,95 \% \mathrm{CI}=1.085-49.040$, $P=0.041$ ).

\section{Discussion}

Almost all the respondents in this study were aware of the Internet and the mass media, with more than 9 of 10 respondents knowing about the various forms of mass media. This is similar to what has been reported in earlier studies, ${ }^{1,3}$ and it is expected because young people have been said to be vigorous users of the mass media. ${ }^{9}$ Only about a fifth of the students in this study had ready access to radio and television, and even fewer (15\%) had ready access to the Internet. 
Table 4 Attitudes of respondents to mass media/the Internet $(n=400)$

\begin{tabular}{|c|c|c|c|c|c|}
\hline Variables & $\begin{array}{l}\text { Strongly agree } \\
\text { n (\%) }\end{array}$ & $\begin{array}{l}\text { Agree } \\
\text { n (\%) }\end{array}$ & $\begin{array}{l}\text { Undecided } \\
\text { n (\%) }\end{array}$ & $\begin{array}{l}\text { Disagree } \\
\text { n (\%) }\end{array}$ & $\begin{array}{l}\text { Strongly disagree } \\
\text { n (\%) }\end{array}$ \\
\hline Premarital sex is acceptable to me & $27(6.8)$ & $69(17.3)$ & $75(18.8)$ & $72(18.0)$ & $157(39.3)$ \\
\hline $\begin{array}{l}\text { Accessing the Internet for sexual material } \\
\text { or movies is acceptable to me }\end{array}$ & $27(6.8)$ & $74(18.5)$ & $52(\mid 3.0)$ & $84(21.0)$ & $163(40.7)$ \\
\hline $\begin{array}{l}\text { The Internet has a bad influence } \\
\text { on youths' sexual behavior }\end{array}$ & $152(38.0)$ & $142(35.5)$ & $48(12.0)$ & $36(9.0)$ & $22(5.5)$ \\
\hline $\begin{array}{l}\text { Frequent exposure to mass media is likely } \\
\text { to promote sexual permissiveness among youth }\end{array}$ & $120(30.0)$ & $56(14.0)$ & $44(11.0)$ & $31(7.7)$ & $149(37.3)$ \\
\hline $\begin{array}{l}\text { Protected sex (use of condoms) could } \\
\text { be encouraged among youth through mass media }\end{array}$ & $163(40.8)$ & $143(35.8)$ & $49(12.2)$ & $29(7.2)$ & $16(4.0)$ \\
\hline $\begin{array}{l}\text { It is the modern time now, and youths } \\
\text { could be involved in premarital sex }\end{array}$ & $97(24.3)$ & $180(45.0)$ & $36(9.0)$ & $4 \mathrm{I}(10.2)$ & $46(11.5)$ \\
\hline
\end{tabular}

Abbreviation: $\mathrm{n}$, number.

This differs from what has been reported in other studies, which generally have found that most adolescents have access to the mass media and the Internet. ${ }^{1-3,10,23}$ This may not be surprising, however, as these previous studies were carried

Table 5 Sexual behaviors of respondents $(n=400)$

\begin{tabular}{|c|c|}
\hline Variables & n (\%) \\
\hline \multicolumn{2}{|c|}{ Awareness of forms of sex behavior (multiple responses allowed) } \\
\hline Masturbation & $357(89.2)$ \\
\hline Oral sex & $352(88.0)$ \\
\hline Anal sex & $339(84.7)$ \\
\hline Coitus & $400(100.0)$ \\
\hline \multicolumn{2}{|c|}{ Sexually experienced } \\
\hline Yes & $226(56.5)$ \\
\hline No & 174 (43.5) \\
\hline \multicolumn{2}{|c|}{ Most recent sexual exposure $(n=226)$} \\
\hline Last I week & $103(45.6)$ \\
\hline Last 3 months & $46(20.4)$ \\
\hline Last 6 months & $32(14.1)$ \\
\hline Others & $45(19.9)$ \\
\hline \multicolumn{2}{|c|}{ Practice of forms of sexual behavior $(n=226)$} \\
\hline \multicolumn{2}{|c|}{ (multiple responses allowed) } \\
\hline Masturbation & $31(13.7)$ \\
\hline Oral sex & $37(16.4)$ \\
\hline Anal sex & $10(4.4)$ \\
\hline Coitus & $226(100.0)$ \\
\hline \multicolumn{2}{|c|}{ Frequency of condom use $(n=226)$} \\
\hline Always & $122(54.0)$ \\
\hline Occasionally & $14(6.0)$ \\
\hline Never & $90(40.0)$ \\
\hline \multicolumn{2}{|c|}{ Sex with commercial sex workers $(n=226)$} \\
\hline Yes & $33(14.6)$ \\
\hline No & $193(85.4)$ \\
\hline \multicolumn{2}{|c|}{ Age at first intercourse (years) $(n=226)$} \\
\hline Less than 15 & II (4.9) \\
\hline $15-19$ & II7 (5।.8) \\
\hline $20-24$ & $65(28.7)$ \\
\hline $25-30$ & $33(14.6)$ \\
\hline \multicolumn{2}{|c|}{ Current number of sexual partners $(n=226)$} \\
\hline None & $45(19.9)$ \\
\hline $\mathrm{I}-2$ & |7| (75.7) \\
\hline $3-5$ & $10(4.4)$ \\
\hline
\end{tabular}

Abbreviation: $\mathrm{n}$, number. out in developed countries where information technology is not only more advanced, but also more readily affordable and accessible than it is in developing countries like Nigeria.

Regarding sexually explicit materials, most of the respondents opined that the Internet $(\sim 40 \%)$ and radio and television $(\sim 25 \%)$ were sources of sexually explicit materials. This has been similarly reported in other studies. ${ }^{10,20}$

Table 6 Association between sexual activity and other characteristics of respondents $(n=400)$

\begin{tabular}{|c|c|c|c|c|}
\hline \multirow[t]{2}{*}{ Variable } & \multicolumn{2}{|c|}{ Sexually active } & \multirow[t]{2}{*}{$\chi^{2}$} & \multirow[t]{2}{*}{$P$-value } \\
\hline & No (\%) & Yes (\%) & & \\
\hline \multicolumn{5}{|c|}{ Age groups (years) } \\
\hline Less than 20 & I 4 (82.4) & $3(17.6)$ & 15.4 & 0.001 \\
\hline $20-24$ & $101(42.4)$ & I 37 (57.6) & & \\
\hline $25-29$ & $57(43.5)$ & $74(56.5)$ & & \\
\hline 30 and above & $2(14.3)$ & $12(85.7)$ & & \\
\hline \multicolumn{5}{|l|}{ Sex } \\
\hline Female & II 3 (49.8) & II 4 (50.2) & 8.4 & 0.004 \\
\hline Male & $61(35.3)$ & II 2 (64.7) & & \\
\hline \multicolumn{5}{|l|}{ Marital status } \\
\hline Single & $168(45.2)$ & $204(54.8)$ & 6.0 & 0.01 \\
\hline Married & $6(21.4)$ & $22(78.6)$ & & \\
\hline \multicolumn{5}{|c|}{ Time spent watching television daily (hours) $(\mathrm{n}=34 \mathrm{I}$; no response $=59$ ) } \\
\hline $0-2$ & $49(40.5)$ & $73(59.5)$ & 6.7 & 0.03 \\
\hline $3-5$ & $57(42.5)$ & $77(57.5)$ & & \\
\hline More than 5 & $22(25.9)$ & $63(74.1)$ & & \\
\hline \multicolumn{5}{|c|}{ Frequency of Internet use* } \\
\hline Often & $66(33.7)$ & $132(66.3)$ & 16.6 & 0.0003 \\
\hline Occasionally & $63(53.8)$ & $53(46.2)$ & & \\
\hline Rarely & $45(46.3)$ & $41(53.7)$ & & \\
\hline \multicolumn{5}{|c|}{ Frequency of accessing sexually explicit materials $(n=298)^{*}$} \\
\hline Often & $12(2 \mid .4)$ & $44(78.6)$ & 14.8 & 0.001 \\
\hline Occasionally & $16(30.2)$ & $37(69.8)$ & & \\
\hline Rarely & $90(47.6)$ & $99(52.4)$ & & \\
\hline \multicolumn{5}{|c|}{ Place of residence } \\
\hline Rural & $25(54.3)$ & $21(45.7)$ & 2.5 & 0.11 \\
\hline Urban & $149(42.1)$ & $205(57.9)$ & & \\
\hline
\end{tabular}

Note: *Often indicates daily to weekly use; occasionally indicates once or twice a month; and rarely indicates once in two to three months.

Abbreviation: $\mathrm{n}$, number. 
Table 7 Binary logistic regression of sexual activity against its possible predictors $(n=400)$

\begin{tabular}{|c|c|c|c|c|c|}
\hline \multirow[t]{2}{*}{ Variables } & \multirow[t]{2}{*}{ Categories of variable } & \multirow[t]{2}{*}{$P$-value } & \multirow[t]{2}{*}{ Odds ratio } & \multicolumn{2}{|c|}{$95 \%$ confidence intervals } \\
\hline & & & & Lower & Upper \\
\hline Sex & Male (reference) & 0.129 & 0.620 & 0.335 & 1.149 \\
\hline \multirow[t]{3}{*}{ Ethnicity } & Hausa (reference) & 0.020 & & & \\
\hline & Yoruba & 0.978 & 0.969 & 0.106 & 8.852 \\
\hline & lbo & 0.287 & 3.613 & 0.339 & 38.521 \\
\hline Number of television viewing hours & Above the mean (reference) & 0.445 & 0.774 & 0.400 & 1.496 \\
\hline Age & $\geq 25$ years (reference) & 0.142 & 0.575 & 0.275 & 1.204 \\
\hline Level in school* & Upper level (reference) & 0.097 & 1.825 & 0.898 & 3.709 \\
\hline \multirow[t]{3}{*}{ Frequency of Internet use ${ }^{\dagger}$} & Rarely (reference) & 0.115 & & & \\
\hline & Often & 0.094 & 2.095 & 0.883 & 4.974 \\
\hline & Occasionally & 0.757 & 1.158 & 0.456 & 2.942 \\
\hline Accessing the Internet for sexual & Agree (reference) & $<0.001$ & & & \\
\hline \multirow[t]{2}{*}{ material/movies is acceptable to me } & Disagree & $<0.00 \mathrm{I}^{\ddagger}$ & 0.043 & 0.016 & 0.122 \\
\hline & Undecided & 0.050 & 0.279 & 0.078 & 0.998 \\
\hline Marital status & Ever married (reference) & $0.021^{\ddagger}$ & 0.075 & 0.008 & 0.679 \\
\hline
\end{tabular}

Notes: *Lower level includes first-year to third-year students; upper level includes fourth-year and fifth-year students; †often indicates daily to weekly use; occasionally indicates once or twice a month; and rarely indicates once in two to three months; ‡statistically significant.

Abbreviation: $\mathrm{n}$, number.

Several studies have shown clearly that sexual content is prevalent on television. ${ }^{24-26}$ The Internet has also been said to make sexually explicit materials more accessible to youth than ever before. ${ }^{10,27}$ Approximately $17 \%$ of respondents also considered home videos to be a source of sexually explicit materials, and a little more than that felt that these also affect sexual behavior. This has been corroborated by other studies, ${ }^{28-30}$ and it has been reported that sexual content is more explicit in movies than on television. ${ }^{10}$

Interestingly, despite the fact that most of the respondents considered the Internet to be a source of sexually explicit materials and to have effect on their sexual behaviors, most of them also considered the Internet to be their favorite source of information and entertainment. It is therefore surprising that only a few studies (and even fewer studies in developing countries) have examined the sexual content of the Internet in relation to the sexual behavior of the young people. There is a great deal of existing literature on the influence of mass media on the behaviors of adolescents and young adults, particularly in the United States and other Western cultures; thus, the strength of this study is that it is assessing a country where not as much research has been done on the relationship between mass media and sexual behavior.

Table 8 Binary logistic regression of multiple sexual partners against its possible predictors $(n=400)$

\begin{tabular}{|c|c|c|c|c|c|}
\hline \multirow[t]{2}{*}{ Variables } & \multirow[t]{2}{*}{ Categories of variable } & \multirow[t]{2}{*}{$P$-value } & \multirow[t]{2}{*}{ Odds ratio } & \multicolumn{2}{|c|}{$95 \%$ confidence intervals } \\
\hline & & & & Lower & Upper \\
\hline Sex & Male (reference) & $0.022 *$ & 0.308 & 0.113 & 0.843 \\
\hline \multirow[t]{3}{*}{ Ethnicity } & Hausa (reference) & 0.021 & & & \\
\hline & Yoruba & 0.161 & 0.144 & 0.010 & 2.167 \\
\hline & Ibo & $0.014 *$ & 0.022 & 0.001 & 0.465 \\
\hline Number of television viewing hours & Above the mean (reference) & 0.786 & 0.875 & 0.332 & 2.300 \\
\hline Age & $\geq 25$ years (reference) & 0.124 & 0.388 & 0.116 & 1.296 \\
\hline Level in school ${ }^{\dagger}$ & Upper level (reference) & 0.848 & 0.889 & 0.266 & 2.967 \\
\hline \multirow[t]{3}{*}{ Frequency of Internet use ${ }^{\ddagger}$} & Rarely (reference) & 0.101 & & & \\
\hline & Often & $0.045 *$ & 5.450 & 1.035 & 28.703 \\
\hline & Occasionally & $0.041 *$ & 7.295 & 1.085 & 49.040 \\
\hline Accessing the Internet for sexual & Agree (reference) & 0.262 & & & \\
\hline \multirow[t]{2}{*}{ material/movies is acceptable to me } & Disagree & 0.122 & 0.376 & 0.109 & 1.300 \\
\hline & Undecided & 0.955 & 0.966 & 0.288 & 3.243 \\
\hline Marital status & Ever married (reference) & 0.999 & 0.000 & 0.000 & 0.001 \\
\hline
\end{tabular}

Notes: *Statistically significant; †lower level includes first-year to third-year students; upper level includes fourth-year and fifth-year students; ${ }^{\circ}$ often indicates daily to weekly use; occasionally indicates once or twice a month; and rarely indicates once in two to three months.

Abbreviation: $\mathrm{n}$, number. 
Two thirds of the respondents learned about the Internet from friends and less than $4 \%$ from parents. This pattern is likely to result in varied and unbalanced information, often with poor quality. Respondents' main reasons for using the Internet were for school assignments and email; however, three quarters of the respondents also used the Internet to view sexually explicit movies and pornography. This is similar to what was reported in a study of 813 university students from across the United States, in which $87 \%$ of the males and $31 \%$ of the females reported seeking out pornography themselves. ${ }^{31}$ This calls for concern, because the Internet and mass media may be the sources of first impressions and ongoing perceptions that are critical in the development of a young person's sexual attitudes, expectations, and behaviors. If young people's initial explorations of sex happen in the context of the online "sexual marketplace," 10 it will be difficult for them to develop healthy concepts of sex and their own sexuality. Young adolescents are shaped by their experiences. Furthermore, sexually explicit content may present new ideas, which in turn may influence an adolescent's development of values and perception of healthy sexual relationships. The sexually explicit information found on the Internet is often inaccurate and harmful. It often lacks descriptions of intimacy or the development of deep personal relationships. Rather, it encourages sexual acts without any emotional connection, which in turn may begin to shape a person's sexual values, attitudes, and behaviors, and consequently may interfere with healthy sexual development.

In this regard, it is critical to view the Internet as a new social environment in which universal adolescent issues pertaining to identity formation, sexuality, and self-worth are explored in a virtual world. Easy and continuous access to the Internet provides tremendous opportunities for adolescent socialization, allowing them to connect with their peers as well as with complete strangers from across the world. Clearly, the Internet is transforming the social world of adolescents by influencing how they communicate, establish and maintain relationships, and find social support. Therefore, it is essential to gain awareness of both the potential benefits and risks of teen Internet use and to provide strategies to guide safe and positive practice.

Half of the respondents said they used the Internet often, and there was a significant association between frequency of Internet use and frequency of accessing sexually explicit materials on the Internet, with frequent users of the Internet more likely to frequently access sexually explicit materials. There was also a significant association between being sexually active and the frequency of Internet use and frequency of accessing sexually explicit materials on the Internet, with those who used the Internet or accessed sexually explicit materials often being more likely to be sexually active. This is similar to the finding of Brown et al, ${ }^{32}$ who in their longitudinal study found that the quintile of teens who consumed the greatest amount of sexual-media content in early adolescence were more than twice as likely as those with lighter sexual-media diets to have initiated sexual intercourse by the time they were 16 years old. This may be another reason for concern about increasing access to mass media/ the Internet, especially with the advent of mobile phones, laptops, and other portable electronic devices with facilities for accessing the Internet and watching movies.

About 6 of 10 respondents had poor attitudes towards mass media/the Internet and their sexual behavior, and a quarter of them considered viewing sexually explicit materials or sex movies on the Internet to be acceptable. This is similar to what was reported in a study carried out among undergraduates in the United States, wherein two thirds of the males and half of the females considered viewing pornography to be acceptable. ${ }^{31}$ Nearly $60 \%$ of the respondents in the current study were sexually active, with nearly half of these having had their most recent sexual exposure within a week before data collection. This pattern has been reported in earlier studies generally showing that young adults, especially those in developing countries, are becoming more sexually experienced. ${ }^{33,34}$ It was, however, interesting to find a significant relationship between being sexually active and factors such as time spent watching television and frequency of Internet use. This relationship also has been reported in previous studies. Peterson et $\mathrm{a}^{35}$ found an association between duration of television viewing and early initiation of sexual intercourse among adolescents. Brown and Newcomer ${ }^{11}$ also found that junior-high-school students who watched television with more sexual content were more likely to have initiated sexual activity than were those who watched less sexual-media content.

More than 9 of 10 respondents in this study felt that mass media/the Internet had an effect on their sexual behavior, and about half of them believed the effect was both positive and negative. This is similar to the opinions shared by previous authors. ${ }^{1,3}$ The Internet might have a positive effect on teenagers, as there are some sites that create awareness about teen pregnancy, human immunodeficiency virus, and sexually transmitted diseases. These sites could be used by young people when they have nowhere else to turn. However, research has shown that mass media/the Internet can also negatively influence young people's sexual behavior because teenagers are more likely to start having sexual relationships earlier 
without using protection. ${ }^{1,3}$ Multivariate analysis showed that acceptability of accessing the Internet for sexual materials was a predictor of the likelihood of being sexually active; the frequency of Internet use for accessing sexual materials/ pornography was also found to be predictive of respondents' likelihood of having multiple sexual partners. These findings corroborate reports from other researchers on the negative influence that Internet use may have on adolescents' sexual behaviors. ${ }^{1,3,11,32,35}$

\section{Conclusion and recommendations}

Most of the respondents in this study were aware of the various forms of mass media and the Internet, although only a few of them had ready access to these. Most of the respondents spent 3-5 hours a day watching television, and most also used the Internet often. There was a significant relationship between sexual activity, time spent watching television, and the frequency of Internet use: those who spent more time watching television and those who used the Internet more frequently were more likely to be sexually active. Frequency of Internet use for accessing sexual materials was found to be a predictor of being sexually active and of the likelihood of having multiple sexual partners.

On the basis of these findings, the authors recommend that young people be educated on the proper use of mass media/the Internet. The directors and producers of programs broadcasted on mass media/the Internet should be educated on the need to balance portrayals of sexual activity with the possible consequences of choices in sexual behavior. Parents are also encouraged to be involved in their children's patterns and choices of mass media and Internet use. Families should regularly discuss with their children the limitations of the information in the mass media and its potential misuse in relation to reproductive health and rights. As a matter of support, parents should adhere to the available rule of "parental guidance" when watching certain movies and programs in the mass media, most especially on television and the Internet. Because Nigerian undergraduates are required to take a general course on information and communication technology as a way of acquiring basic knowledge in this arena, colleges and institutions should use this opportunity to educate students on the use and misuse of the mass media and proper use of the Internet as source of information on sexual issues.

\section{Disclosure}

The authors report no conflicts of interest in this work.

\section{References}

1. Anton. Mass Media and Adolescence: How Mass Media Influence Teens In Their Sexual Behavior. Essays24.com; 2010. Available from: http:// essays24.com/print/Mass-Media-Adolescence-Mass-Media/24866. html. Accessed June 15, 2011.

2. Wakefield MA, Loken B, Hornik RC. Use of mass media campaigns to change health behaviour. Lancet. 2010;376(9748):1261-1271.

3. Brown JD. Mass media influences on sexuality. J Sex Res. 2002;39(1): $42-45$.

4. Corder-Bolz C. Television and adolescents' sexual behavior. Sex Education Coalition News. 1981;3:40.

5. Brown JD, Greenberg BS, Buerkel-Rothfuss NL. Mass media, sex, and sexuality. Adolesc Med. 1993;4(3):511-552.

6. Greenberg BS, Brown JD, Buerkel-Rothfuss N. Media, Sex, and the Adolescent. Cresskill, NJ: Hampton Press; 1993.

7. Malamuth NM. Pornography's impact on male adolescents. Adolesc Med. 1993;4(3):563-576.

8. Malamuth NM, Impett EA. Research on sex in the media: what do we know about effects on children and adolescents? In: Singer DG, Singer JL, editors. Handbook of Children and the Media. Thousand Oaks, CA: Sage Publications; 2001:269-287.

9. Werner-Wilson RJ, Fitzharris JL, Morrissey KM. Adolescent and parent perceptions of media influence on adolescent sexuality. Adolescence. 2004;39(154):303-313.

10. Rich M. Virtual Sexuality: The Influence of Entertainment Media on Sexual Attitudes and Behavior. Washington, DC. The National Campaign to Prevent Teen and Unplanned Pregnancy; 2008. Available from: http://www.thenationalcampaign.org/resources/monster/ MM_1.0.pdf. Accessed June 10, 2011.

11. Brown JD, Newcomer SF. Television viewing and adolescents' sexual behavior. J Homosex. 1991;21(1-2):77-91.

12. Stern SE, Handel AD. Sexuality and mass media: the historical context of psychology's reaction to sexuality on the Internet. $J$ Sex Res. 2001;38(4):283-291.

13. Gruber E, Grube JW. Adolescent sexuality and the media: a review of current knowledge and implications. West J Med. 2000;172(3):210-214.

14. Sprafkin JN, Silverman LT. Update: physically intimate and sexual behavior on prime-time television. J Commun. 1981;31(1):34-40.

15. Bragg S, Buckingham D. Young people and sexual content on television: a review of the research. The Broadcasting Standards Commission; 2002. Available from http://citeseerx.ist.psu.edu/viewdoc/download? doi=10.1.1.133.2116\&rep=rep1\&type=pdf. Accessed January 9, 2014.

16. Collins RL, Martino SC, Shaw R. Influence of New Media on Adolescent Sexual Health: Evidence and Opportunities. RAND; 2011. Available from: http://www.rand.org/pubs/working_papers/WR761. html. Accessed January 9, 2014.

17. Lowry DT, Towles DE. Prime Time TV Portrayals of Sex, Contraception and Venereal Diseases. Journalism Quarterly. 1989;66(2):347-352.

18. Idowu B, Ogunbodede E, Idowu B. Information and Communication Technology in Nigeria: The Health Sector Experience. Journal of Information Technology Impact. 2003;3(2):69-76.

19. Kunkel D, Cope KM, Farinola WJM, Biely E, Rollin E, Donnerstein E. Sex on TV: A Biennial Report to the Kaiser Family Foundation. Menlo Park, CA: the Henry J Kaiser Family Foundation; 1999.

20. Fisher DA, Hill DL, Grube JW, Gruber EL. Sex on American television: an analysis across program genres and network types. $J$ Broadcast Electron Media. 2004;48(4):529-553.

21. Olasode OA. Sexual behaviour in adolescents and young people attending a sexually transmitted disease clinic, Ile Ife, Nigeria. Indian J Sex Transm Dis. 2007;28(2):83-86.

22. Araoye MO. Research Methodology with Statistics for Health and Social Sciences. Ilorin, Nigeria: Nathadex Publishers; 2004:117-120.

23. Roberts DF. Media and youth: access, exposure, and privatization. J Adolesc Health. 2000;27(Suppl 2):8-14. 
24. Davis S, Mares ML. Effects of talk show viewing on adolescents. J Commun. 1998;48(3):69-86.

25. Strouse JS, Buerkel-Rothfuss N, Long EC. Gender and family as moderators of the relationship between music video exposure and adolescent sexual permissiveness. Adolescence. 1995;30(119): 505-521.

26. Kunkel D, Cope KM, Biely E. Sexual messages on television: comparing findings from three studies. J Sex Res. 1999;36(3):230-236.

27. Kanuga M, Rosenfeld WD. Adolescent sexuality and the internet: the good, the bad, and the URL. J Pediatr Adolesc Gynecol. 2004;17(2): $117-124$.

28. Thompson KM, Yokota F. Violence, sex and profanity in films: correlation of movie ratings with content. MedGenMed. 2004;6(3):3.

29. Bufkin J, Eschholz S. Images of sex and rape: A content analysis of popular film. Violence against Women. 2000;6(12):1317-1344.

30. Oliver MB, Kalyanaraman S. Appropriate for all viewing audiences? An examination of violent and sexual portrayals in movie previews featured on video rentals. J Broadcast Electron Media. 2002;46(2):283-299.
31. Carroll JS, Padilla-Walker LM, Nelson LJ, Olson CD, Barry CM, Madsen SD. Generation XXX: pornography acceptance and use among emerging adults. J Adolesc Res. 2008;23(1):6-30.

32. Brown JD, L'Engle KL, Pardun CJ, Guo G, Kenneavy K, Jackson C. Sexy media matter: exposure to sexual content in music, movies, television, and magazines predicts black and white adolescents' sexual behavior. Pediatrics. 2006;117(4):1018-1027.

33. Santelli JS, Brener ND, Lowry R, Bhatt A, Zabin LS. Multiple sexual partners among US adolescents and young adults. Fam Plann Perspect 1998;30(6):271-275.

34. Yan $\mathrm{H}$, Chen $\mathrm{W}, \mathrm{Wu} \mathrm{H}$, et al. Multiple sex partner behavior in female undergraduate students in China: a multi-campus survey. BMC Public Health. 2009;9:305.

35. Peterson JL, Moore KA, Furstenberg FF Jr. Television viewing and early initiation of sexual intercourse: is there a link? J Homosex. 1991;21(1-2):93-118.
Adolescent Health, Medicine and Therapeutics

\section{Publish your work in this journal}

Adolescent Health, Medicine and Therapeutics is an international, peer-reviewed, open access journal focusing on health, pathology, and treatment issues specific to the adolescent age group. All aspects of health maintenance, preventative measures and disease treatmen interventions are addressed within the journal and practitioners from

\section{Dovepress}

all disciplines are invited to submit their work as well as healthcare researchers and patient support groups.. The manuscript management system is completely online and includes a very quick and fair peerreview system. Visit http://www.dovepress.com/testimonials.php to read real quotes from published authors.

Submit your manuscript here: http://www.dovepress.com/adolescent-health-medicine-and-therapeutics-journal 